ENTREPRENEURSHIP AND SUSTAINABILITY ISSUES

ISSN 2345-0282 (online) http://jssidoi.org/jesi/

2021 Volume 9 Number 1 (September)

http://doi.org/10.9770/jesi.2021.9.1(20)

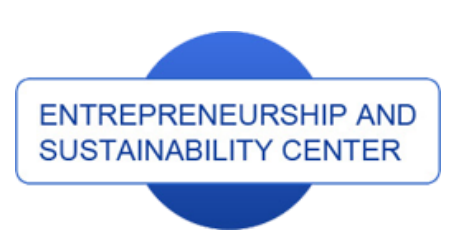

Publisher

$\underline{\text { http://jssidoi.org/esc/home }}$
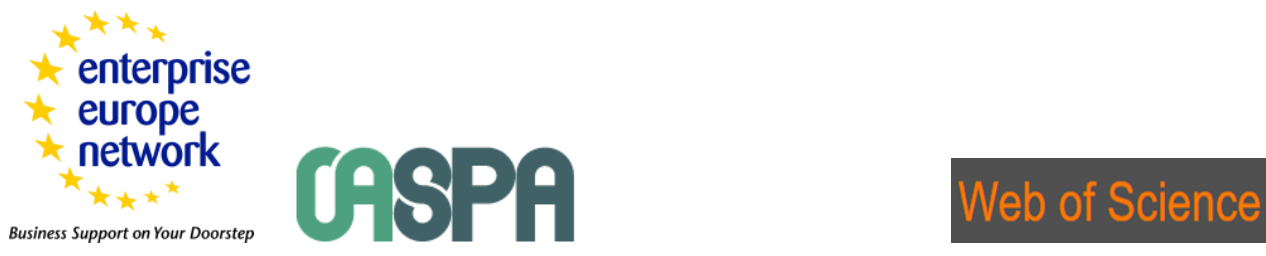

Clarivate
Analytics

\title{
DETERMINANTS OF ENTREPRENEURSHIP DEVELOPMENT IN POLAND OVER THE LAST 5 YEARS
}

\author{
Michal Igielski \\ Gdynia Maritime University, 81-87 Morska St., 81-225 Gdynia, Poland \\ E-mail: m.igielski@wznj.umg.edu.pl
}

Received 2 May 2021; accepted 29 June 2021; published 30 September 2021

\begin{abstract}
The main objective of the article is an attempt to identify factors/determinants conditioning the development of enterprises in Poland over the last 5 years. The author will also try to indicate the dominant behaviours related to the notion of entrepreneurship among the owners of the enterprises under study and identify the relations between the variables related to enterprise management and its development and growth. In addition to the literature analysis, the author chose a survey in the form of a structured interview with business owners as another research method - the survey was carried out in 2018 and 2019 in 200 purposively selected enterprises from the SME sector, which are based in Poland and were established in the last 5 years. After the analysis of the literature and the results of the conducted survey, obviously bearing in mind its pilot character, the author clarified the names of the selected indicators/determinants and expanded their list by those he considered useful from the point of view of the general purpose of the survey - 9 indicators/determinants. In the author's opinion, the developed indicators/determinants make it possible to assess the level of enterprise development (direction and pace of changes) depending on selected factors of the local and institutional environment, internal factors, the level of achieved financial results, sources of financing.
\end{abstract}

Keywords: entrepreneurship; entrepreneurship development; determinants / factors of enterprise development

Reference to this paper should be made as follows: Igielski, M. 2021. Determinants of entrepreneurship development in Poland over the last 5 years. Entrepreneurship and Sustainability Issues, 9(1), 330-347. http://doi.org/10.9770/jesi.2021.9.1(20)

JEL Classifications: M12, M13, O11

\section{Introduction}

Already A. Smith pointed out that economic development depends on the three prerogatives that the individual is entitled to - the pursuit of his own interests, the division of labour and freedom of trade. In economic practice, all of them are used, giving the opportunity to achieve the purpose for which economic entities are created (O'Rourke, 2019). 


\section{ENTREPRENEURSHIP AND SUSTAINABILITY ISSUES}

ISSN 2345-0282 (online) http://jssidoi.org/jesi/

2021 Volume 9 Number 1 (September)

http://doi.org/10.9770/jesi.2021.9.1(20)

The very concept of entrepreneurship is a very broad, multifocal, interdisciplinary term. Analyzing the scientific literature, we can see how many definitions of this term work. For the author of the article, the contemporary evolution of the concept of entrepreneurship, which focuses on human attitudes and behaviors, is important. The process of these theses is identified with achieving success, seeing new opportunities, searching for opportunities, achieving goals effectively and maximizing profits. In this context, we should first understand entrepreneurship as the ability of a person or organization to seek and apply new solutions. Secondly, this requires initiative, energy, ingenuity and the ability to estimate the necessary material, financial and time expenditure. Thirdly, we should strive for achievable benefits in the area of existing limitations and opportunities and the willingness to take risks and take responsibility for decisions and actions taken (Say, 2018).

Turbulent economic environment, reinforced by unprecedented technological progress, ubiquitous globalization and global crises, such as the global pandemic COVID 19, which are causing huge changes in national economic markets, including their main players - companies. In the 21 st century, against the background of ever-new economic challenges, the development of entrepreneurship has become a basic condition for the sustainable development of each country. After all, it is its dynamics, regardless of differences in the understanding of its subject and subject structure in economic theory that is an interpretation of economic growth and development. Undertaking economic activity contributes to the revival and social and economic development of entire economies. It also manifests itself in reducing the level of unemployment and increasing revenues to state budgets. Therefore, as the main objective of the article, its author considered the identification of factors determining the development of SME enterprises in Poland in 2018-2020. Of course, taking into account the situation related to the global pandemic, the research covered only the beginning of 2020 . However, it is certainly worth returning to them, at the time of "return to normality", because, in the author's opinion, most of the identified factors have certainly significantly changed their value.

An important element of the research work was to conduct research, at the turn of 2018 and 2019 in 200 intentionally selected enterprises from the SME sector, which are based in Poland and were established in the last 5 years. The information and opinions obtained in this way referred to the current situation of the company and the evaluation of its development in the last 5 years. And also, in a few cases, to opinions on the development prospects of the enterprise in the coming years.

\section{Theoretical background}

The term "entrepreneur" appeared in economic literature at the turn of the 17th and 18th centuries, and it is derived from the French word „entrepreneur”, which describes persons undertaking a certain activity. Suppliers, intermediaries and contractors, for example, began to be referred to as such. The word „entreprendre”, also derived from French, means to undertake. In French, we can also find the term „entreprenant”, which describes a bold, bold, self-confident person, that is, one that has entrepreneurial qualities (Łochnicka, 2016).

However, by analysing the genesis of this concept, we can assume that it has existed since man appeared. On the other hand, we are not able to accept when entrepreneurship appeared in human life - there is no uniform and clearly defined beginning. Of course, the meaning of the term has evolved over the years, and we can give an example or suppose that this was the case at the very beginning of human life on earth.

However, the notion, through the continuous development of mankind acquires more and more new characteristics. Already looking at the primitive people, we can see the beginnings of entrepreneurship - after all, their chances of survival depended largely on creativity, acquired skills and the idea of how to use these skills to hunt the animals or otherwise provide food for themselves and their loved ones. This feature perfectly fits the definition of entrepreneurship known today. By analyzing closer the development of man on earth, we can see the various forms of work, his own ventures, which he has undertaken over the centuries. It has always been 


\section{ENTREPRENEURSHIP AND SUSTAINABILITY ISSUES}

ISSN 2345-0282 (online) http://jssidoi.org/jesi/

2021 Volume 9 Number 1 (September)

http://doi.org/10.9770/jesi.2021.9.1(20)

necessary to look for a job that will meet the expectations of other people and, consequently, bring a measurable income. Profit is nowadays something we directly associate with entrepreneurship.

R. Cantillon is considered to be the precursor of the term entrepreneurship in literature. He drew attention to traders seeking to make money by looking for cheap goods and selling them in places where they will get a higher price. He also pointed out that a typical businessperson takes risks in order to make money - which works perfectly well nowadays, because every attempt to make money on your own, to create a business always involves risk (Thornton, 2019). Whereas according to S. Shane and S. Venkataraman (2013) are all activities that consist of identifying, evaluating and exploiting opportunities to introduce new products and new services, or ways of organizing, new markets.

Analyzing the definitions described above, the author of the article noticed that entrepreneurship can be described in the simplest way as the art of coping with various life situations - it can be trained and learned. However, in the face of complex and rapidly changing reality, the entrepreneurship paradigm is more suitable for explaining contemporary phenomena. Instead of technocratic determinism, a paradigm of a subjective, active role of a person (entrepreneur), who is involved in the competition process through creativity and ingenuity, is proposed. Moreover, he acts under conditions of uncertainty (Kaliszczak \& Sieradzka, 2020). As far as the person of an entrepreneur is concerned, J.B. Say (2012) claimed that an entrepreneur is the one who has his own enterprise - he owns or fully controls it. He is a person who is able to see the opportunities for development and is not afraid to risk it for profit. He introduced a division into types of entrepreneurs: industrial entrepreneur, entrepreneur of the agricultural industry, entrepreneur of the handicraft industry, entrepreneur of the commercial industry - merchant.

The approach to entrepreneurship as an attitude emphasizes the importance of entrepreneurial characteristics: personality, predisposition, general and market knowledge. These are also specific ways of reacting and being ready to take action. The attitude determines behavior and influences its effectiveness. Entrepreneurship is reflected in a creative and active pursuit of improvement of existing states of affairs and expresses readiness to take new actions or expand existing ones. Thus, it is aimed at achieving complex, multi-faceted material benefits. This results in increased income and improved working and living conditions. Entrepreneurial attitudes consist of three elements (Białasiewicz, 2016):

- emotional - moods and feelings;

- behavioral - predispositions to certain behaviors in certain situations;

- cognitive - information, opinions, knowledge, skills.

Despite the passage of many years, since the creation of the above definitions, their validity has survived until today. There are still many companies that only trade, that is, buy goods at certain prices and sell them at a higher amount. It is a much more developed trade considering new means of transport and media, and it still involves a high risk. Looking further ahead, the production and processing of raw materials, i.e. production is not only economically necessary. People need products, and this need is increasing with time, because today's mankind has learned so many conveniences that it would be difficult to do without them and there will be more and more innovative goods. Also portioning in products in smaller quantities is an example of retail trade - the most widespread today. People want to buy products, but in quantities appropriate for them, without bending their budget and systematically buy as the goods are consumed. And it certainly cannot be discussed nowadays that an entrepreneur is the one who has his own company or has full control over one, because he can prove his entrepreneurial skills without having control over any. 


\section{ENTREPRENEURSHIP AND SUSTAINABILITY ISSUES}

ISSN 2345-0282 (online) http://jssidoi.org/jesi/

2021 Volume 9 Number 1 (September)

http://doi.org/10.9770/jesi.2021.9.1(20)

When it comes to formal and legal issues in contemporary business practice in Poland, we can find basic forms of doing business:

1. One-person activity of a natural person: activity conducted by one owner who is responsible for the enterprise with his own property. The owner has full decision-making power. This is one of the simplest forms of setting up a business due to the relatively simple opening process and lack of obligation to make a capital contribution.

2. Civil partnership: the activity is established by at least two persons on the basis of a contract, which should be made in writing. Similarly as in the case of one-person activity, the partners are responsible for the company both its and its property.

3. General partnership: is established by at least two persons on the basis of a contract which should be drawn up in writing under pain of nullity. Each partner is responsible for the partnership with all his assets and must contribute to it. It may be a financial contribution, in kind or intangible.

4. Partnership: is created by the partners (hereafter referred to as partners), who are obliged to run the company in order to exercise their free profession. It can only be created by natural persons. The responsibility for its operation is borne by each partner separately, so that a mistake of one partner does not make the other one responsible.

5. Limited partnership: it is created by the partners on the basis of a notarial deed. It is characterized by the fact that at least one of the partners is responsible for the partnership with all its assets and at least one has limited liability.

6. Limited liability company: a capital company, opened by one or more partners. The partners are not responsible for the company with their own property, but only with the property gathered by them.

To sum up, since the initiation of the term entrepreneurship, its meaning has gradually but systematically changed. In fact, according to the author of the article, under the influence of external determinants, the meaning of its components that make up its meaning has changed. Nowadays, an entrepreneur is associated with a person who has an enterprise and is able to adapt to changing market conditions, which involves taking risks. Additionally, these people must, of course, be boldly committed and dynamic, which translates into an innovative attitude and creativity. They must be gifted with imagination, a feature that is necessary to plan and avoid bad consequences of their decisions. But on the other hand it must be based on „common sense”, because not every decision can be predicted. On the other hand, if bad actions are taken, entrepreneurs must know what steps to take to ensure that the negative impact has the least possible impact on the further operation of their business.

Furthermore, running a business is one of the paths to professional development. Of course, this form has numerous advantages, but often we can also see disadvantages. Undoubtedly, the main advantages include: independence, autonomy in decision-making, freedom to choose the time and place of work. Unfortunately, it is also associated with responsibility, which, as a rule, is borne individually, and quite a high risk of running this type of business may be even greater due to the turbulent environment in the 21 st century.

\section{Research Methodology and data}

The main basis for the briefly described conclusions in the chapter (this is described in detail by the author of the article below) was a study consisting in the assessment of national conditions for the development of entrepreneurship in the micro, small and medium-sized enterprise sector - based on the opinions of entrepreneurs and the analysis of actions taken. The main objective of the study was to identify factors / determinants that determine the development of economic entrepreneurship in Poland over the last 5 years. Author had to apply the following set of research methods:

1. Analysis of the subject literature - to systematize the language of concepts related to entrepreneurship and development. 
2. Questionnaire in the form of a structured interview with business owners - the main element of research work. The author conducted research in 2018 and 2019 in 200 intentionally selected enterprises from the SME sector, which are based in Poland and were established in the last 5 years (Table 1). The information and opinions obtained in this way referred to the current situation of the enterprise. The author also evaluated the development of the enterprise in the last 5 years and in a few cases - to the opinions on the prospects of the enterprise development in the coming years.

Unfortunately, due to financial and organisational limitations, the collected sample does not have the characteristics of the entire population (it should be 72 thousand entities). Therefore, the presented research results are not a complete set - they are the basis for extending the research process in the future - it is a pilot study for now. The author created the questionnaire himself. He chose entrepreneurs as respondents, because they have the greatest knowledge about their companies. The author was also interested in their approach to entrepreneurship, their motivation and their feelings. In this way the author was able to obtain the most suitable information for the purposes of the study. The author used the evaluation method to determine the determinants of entrepreneurship development and actions taken in this area, in the face of new economic challenges. Of course, the author agrees with the opinion that evaluation is always in some way a subjective method. However it is difficult to find a more objective research tool that would be simple enough to induce respondents to participate in the survey. In turn, the author used Statistica version 12. and a Microsoft Excel spreadsheet to carry out statistical calculations.

Table 1. Description of the group of respondents

\begin{tabular}{|c|c|c|c|}
\hline \multicolumn{4}{|c|}{ companies } \\
\hline \multicolumn{4}{|c|}{200} \\
\hline \multicolumn{4}{|c|}{ size } \\
\hline micro & small & \multicolumn{2}{|c|}{ average } \\
\hline 36 & 53 & \multicolumn{2}{|c|}{111} \\
\hline \multicolumn{4}{|c|}{ kind of } \\
\hline business activities & ltd. & \multicolumn{2}{|c|}{ partnership } \\
\hline 98 & 80 & \multicolumn{2}{|c|}{32} \\
\hline \multicolumn{4}{|c|}{ life span } \\
\hline up to 1 year & 2 to 4 years & \multicolumn{2}{|c|}{4 to 5 years } \\
\hline 23 & 137 & \multicolumn{2}{|c|}{40} \\
\hline \multicolumn{4}{|c|}{ industry } \\
\hline maritime & construction & commercial & advisory \\
\hline 35 & 29 & 29 & 36 \\
\hline \multicolumn{4}{|c|}{ entrepreneur } \\
\hline \multicolumn{4}{|c|}{200} \\
\hline \multicolumn{4}{|c|}{ sex } \\
\hline \multicolumn{2}{|l|}{ women } & \multicolumn{2}{|l|}{ men } \\
\hline \multicolumn{2}{|l|}{69} & \multicolumn{2}{|l|}{131} \\
\hline \multicolumn{4}{|c|}{ age } \\
\hline up to 30 & from 31 to 50 & \multicolumn{2}{|c|}{ over 51} \\
\hline 20 & 138 & & \\
\hline & education & & \\
\hline professional & average & & \\
\hline 21 & 81 & & \\
\hline
\end{tabular}

Source: own study

\section{Results}

The author of the article believes that the determinants of the development of enterprises can be divided into two basic categories: factors influencing enterprises from the external environment and internal determinants usually created by the enterprise itself. Going this way and following J. Targalski (2014), the external factors include, 


\section{ENTREPRENEURSHIP AND SUSTAINABILITY ISSUES}

ISSN 2345-0282 (online) http://jssidoi.org/jesi/ 2021 Volume 9 Number 1 (September) http://doi.org/10.9770/jesi.2021.9.1(20)

among others: globalization of the economy; economic prosperity; situation on the foreign and domestic market; innovations; state fiscal policy and legal regulations; level of economic growth; free movement of goods and services. And the composition of the internal factors is: processes taking place in the company; material resources held; management efficiency; business partnerships; objective and strategy; human capital; quality; competitiveness of products and services.

However, for the purposes of this article, the author, after analysing the literature and observing the economic processes taking place on the Polish economic market in recent years, has divided all these factors into four categories: economic, social, administrative / legal and cultural. It is a unique driving force of the company's development or, if the potential is misused, it may become an impulse for the irrevocable failure of the company.

At the beginning it is worth noting that each of the categories contains specific aspects that are able to motivate or demotivate individual individuals to start their own company or not. However, in the opinion of the author of the article, the launch of a particular enterprise will depend solely on the idea of this process of a particular person. Moreover, it will depend on the personal qualities, knowledge, experience and a number of skills and competences, about which the author has already written in a separate study.

Table 2. Determinants/factors of enterprise development in Poland

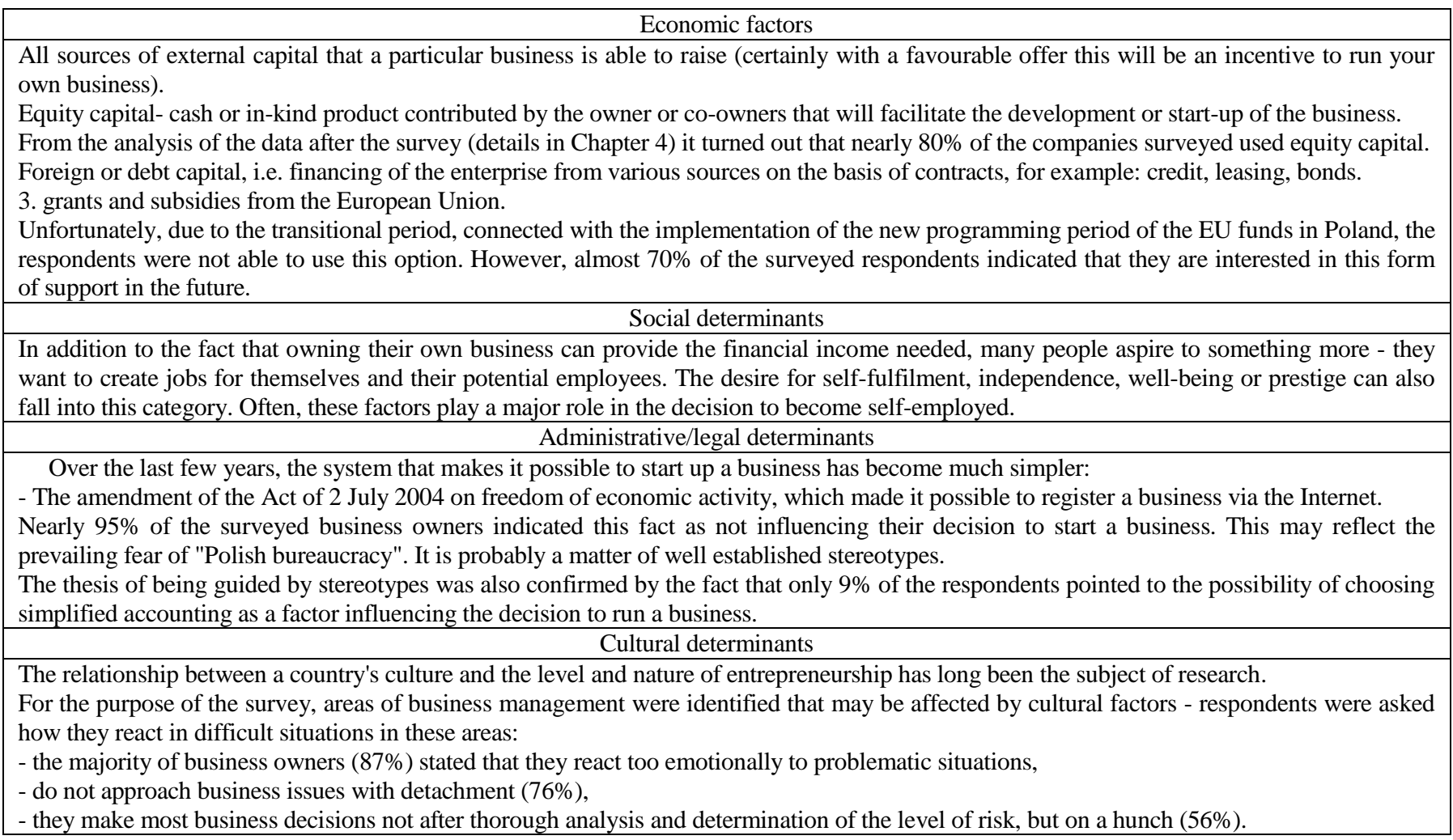

Source: own study

Then, on the basis of the results of the analysis of individual components of entrepreneurship development, the author specified the names of selected indicators/determinants. Ot also extended their list by those he found useful from the point of view of the overall goal of the study - a total of 9 indicators/determinants were developed, which are based on initial methodological assumptions. According to the author of the study the indicators/determinants 


\section{ENTREPRENEURSHIP AND SUSTAINABILITY ISSUES}

ISSN 2345-0282 (online) http://jssidoi.org/jesi/ 2021 Volume 9 Number 1 (September) http://doi.org/10.9770/jesi.2021.9.1(20)

make it possible to assess the level of development of enterprises (direction and pace of changes) depending on selected factors of local and institutional environment, internal factors, level of achieved financial results, sources of financing.

Below (Table 3), the author of the article presented the evaluation of indicators/determinants of development of new and developing companies, made by their owners. It is noteworthy that in each subsequent time period (each year) this evaluation is better than that of the previous year. Most of the nine areas forming the national entrepreneurship determinants identified in this study were rated higher. The best rated areas include:

- access to technical infrastructure - respondents highly evaluate the availability of telecommunications services for new and growing companies, and the costs associated with basic utilities (gas, water, electricity, sewage) are not a problem for tchem;

- $\quad$ the dynamics of the internal market - according to business owners, the Polish market of consumer goods and services and business-to-business is changing significantly from year to year;

- $\quad$ access to external financing - this is an area which is getting better and better evaluated by the respondents year after year and which does not significantly limit the commencement and development of activities in Poland.

In 2019 a significant improvement, according to the respondents, took place in the following areas:

- entrepreneurship education at the level of higher education and lifelong learnin;

- commercial and service infrastructure - the respondents better assessed the ease of obtaining good banking services and professional lawyers and accountants, as well as the ease of obtaining good subcontractors and consultants;

- cultural and social norms - the statements on cultural and social norms were best evaluated in this area in the context of emphasis on self-sufficiency and self-initiative and emphasizing personal responsibility in managing one's life.

In several cases, the ratings of entrepreneurs have decreased, which may indicate a more difficult situation in these areas. These include: burdens related to market openness, dealing with bureaucracy (regulations, consistency and predictability of taxes) and issues related to research and development - for example, effectiveness of technology transfer, access to new knowledge, possibility of acquiring new technologies by young companies. We must also remember that all this information and opinions were collected before the pandemic - the author believes that currently, that is in the fourth quarter of 2020, the situation has certainly changed the opinion of the owners who took part in the survey.

Table 3. Assessment of designated indicators/determinants by respondents

\begin{tabular}{|l|l|c|c|c|}
\hline No & \multicolumn{1}{|c|}{ indicators / determinants } & Poland & Poland & Poland \\
\cline { 3 - 4 } & & 2015 & 2017 & 2019 \\
\hline 1. & access to technical infrastructure & 71 & 96 & 137 \\
\hline 2. & the dynamics of the internal market & 73 & 93 & 128 \\
\hline 3. & consumer goods and services & 56 & 87 & 119 \\
\hline 4. & $\begin{array}{l}\text { entrepreneurship education at the level of higher } \\
\text { education and lifelong learning }\end{array}$ & 78 & 83 & 112 \\
\hline 5. & commercial and service infrastructure & 52 & 76 & 99 \\
\hline 6. & cultural and social norms & 56 & 66 & 89 \\
\hline 7. & burdens related to market openness & 54 & 57 & 50 \\
\hline 8. & dealing with bureaucracy & 41 & 43 & 29 \\
\hline 9. & issues related to research and development & 14 & 25 & 19 \\
\hline
\end{tabular}

Source: own study

A very large number of data that the author obtained during the survey allowed to group and present them in two areas. The first area concerns behaviors related to the concept of entrepreneurship of their owners and their 


\section{ENTREPRENEURSHIP AND SUSTAINABILITY ISSUES}

ISSN 2345-0282 (online) http://jssidoi.org/jesi/ 2021 Volume 9 Number 1 (September) http://doi.org/10.9770/jesi.2021.9.1(20)

subjective opinion about their company. The second area is specific information related to the relations between variables, which are related to the management of the studied entities and their development and growth - these data are discussed and used in another study.

In the first place, according to the author of the article, he must show the motives behind the decision to start his own company. As the main motive were indicated economic issues, which result from the desire to improve the financial situation (73\%). Next, the desire for self-fulfillment and fulfillment of life's desires (60\%), as well as the fear of unemployment (49\%), low income obtained in the previous work, persuasions of family and friends and the willingness to invest their financial resources. There were also voices about the willingness to spend free time, family traditions, as well as necessity - sudden loss of job or lack of suitable offers. A very important element connected with motivation to start a company and also with the development of the company are personality traits of entrepreneurs, which very often determine success in business. These include industriousness, as well as the knowledge resources necessary for making decisions and the risks associated with it, knowledge about the management of the company and the implementation of individual management functions. Also important were professional competences, gained in previous professional experience, as well as consistency in action and perseverance. The respondents considered creativity, responsibility or decision making skills to be less important. This surprised the author of the article (detailed distribution of answers related to motivation and personality traits is shown in Figure 1.

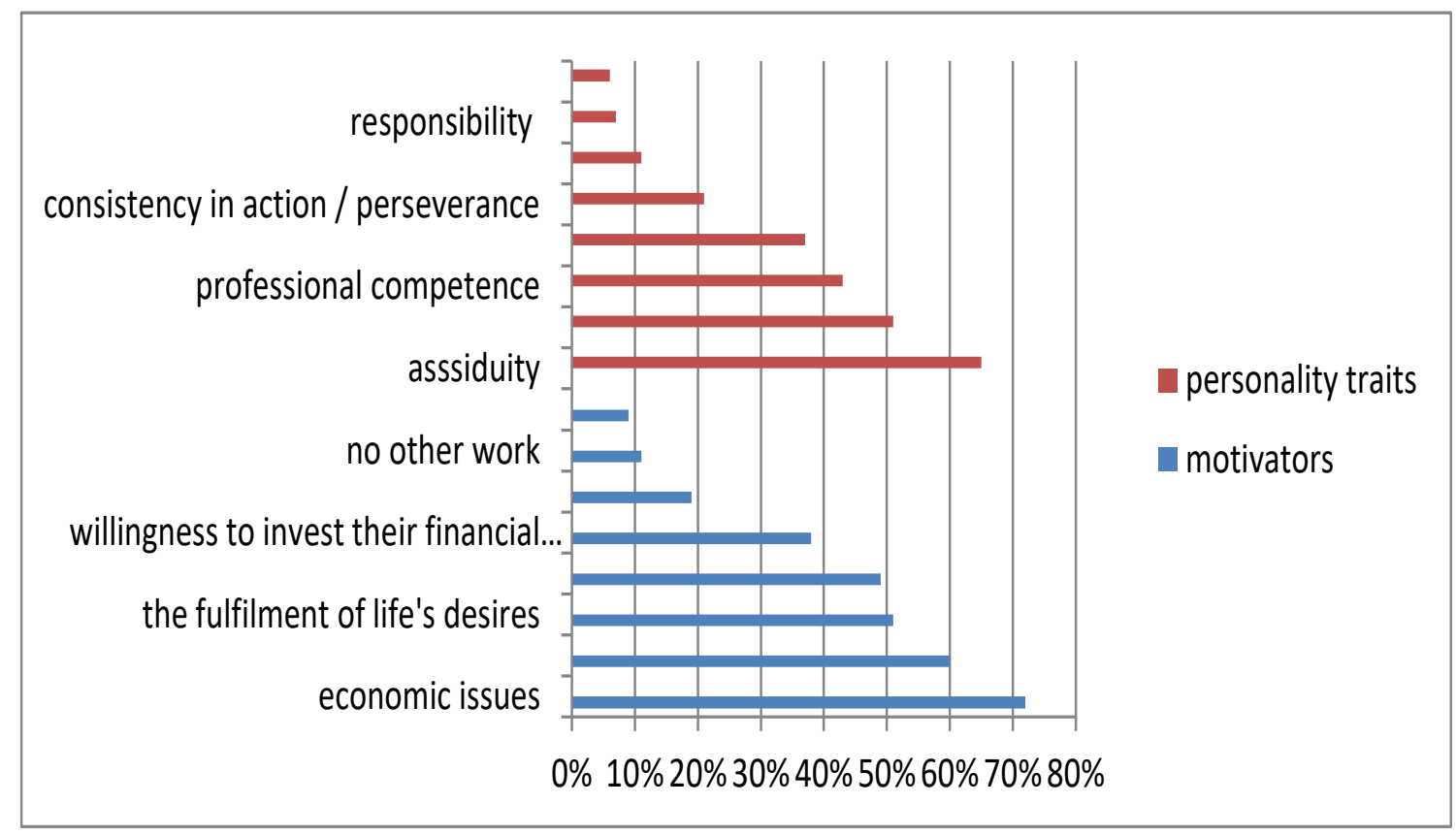

Figure 1. Motives for starting up your own business and personality traits that determine success in business

Source: own study

Analyzing the collected data in terms of sources of financing at the start of business activity, the author stated that the respondents indicated mainly their own funds and bank loans. Among other sources they also pointed to loans from family and non-bank financial institutions. On the other hand, loans from friends, donations, shareholders' own contribution or inheritance received were the least frequently used. This tendency was also confirmed when asked about the most important barriers (limitations) to the development of business activity, which the 
respondents included the lack of funds to start up, high costs associated with the activity (including too high taxes) and difficulties in completing an optimal staff. This confirmed the author's assumptions about the commonly known weakness of small companies, which consists in the lack of own financial resources and difficulties in obtaining credit. This does not only apply to the initiation phase, but also to the development phase. On the one hand, small scale of activity, on the other hand, very high unit costs of created products/services, cause significant disproportions between entities from the SME sector and large enterprises, in terms of costs and revenues incurred. Moreover, smaller companies are more susceptible to competition, which is a result of market saturation with entities with similar offer. All this combined with the internal conditions related to the resources of these economic entities causes that the number of barriers and unfavorable factors makes it permanently difficult for them to function on the already turbulent economic market (Figure 2).

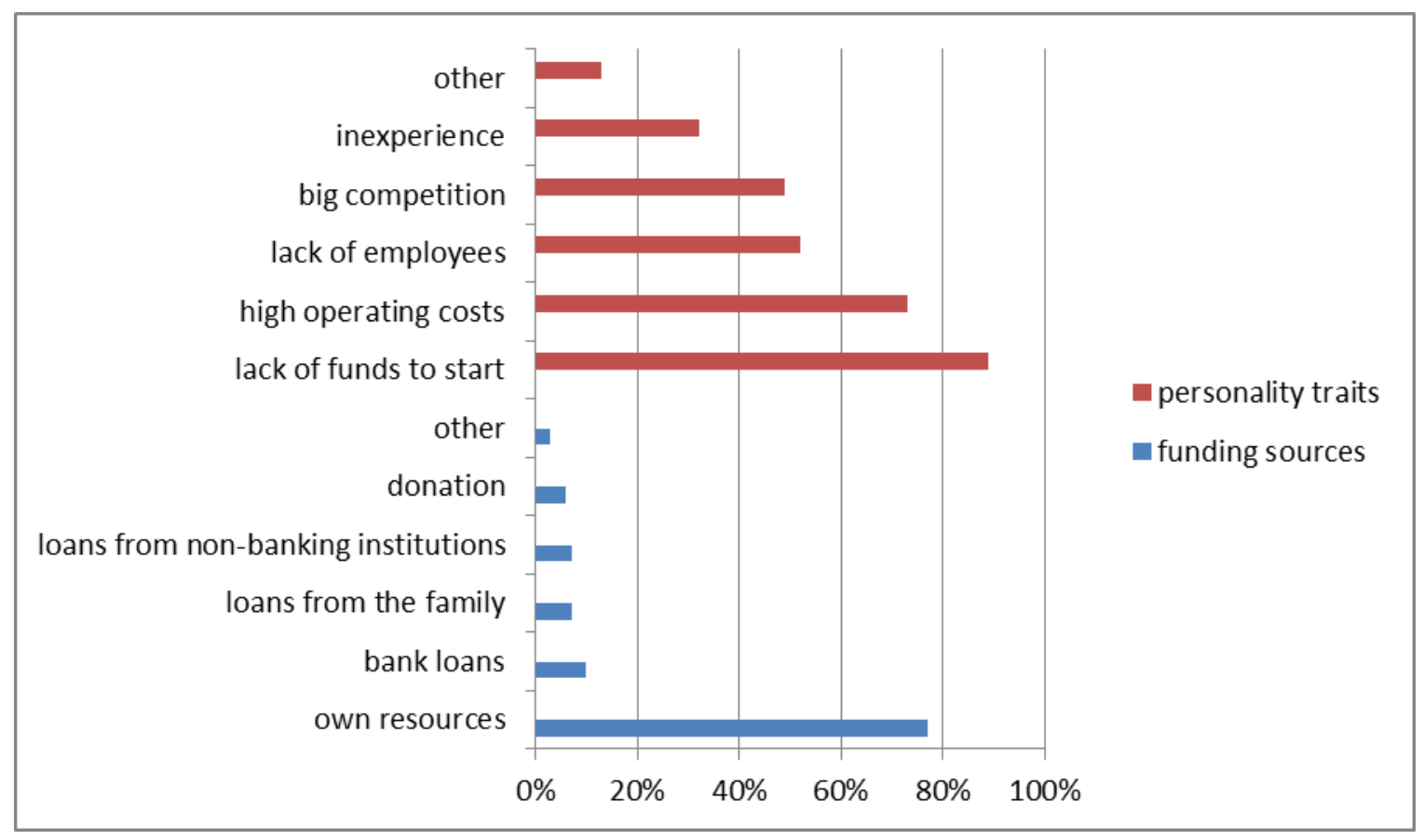

Figure 2. Sources of business financing and barriers that hinder development

Source: own study

In their attempt to assess the possibilities of development of their own company, the respondents strongly emphasized three main areas of their activity: the level of sales, the portfolio of products/services and the sales market. What is important in their forecasts, they looked positively into the future - more than $70 \%$ of the respondents believed that they would increase their sales thanks to the extended portfolio (71\%), and 69\% of them were sure to increase their current sales market (Figure 3). 


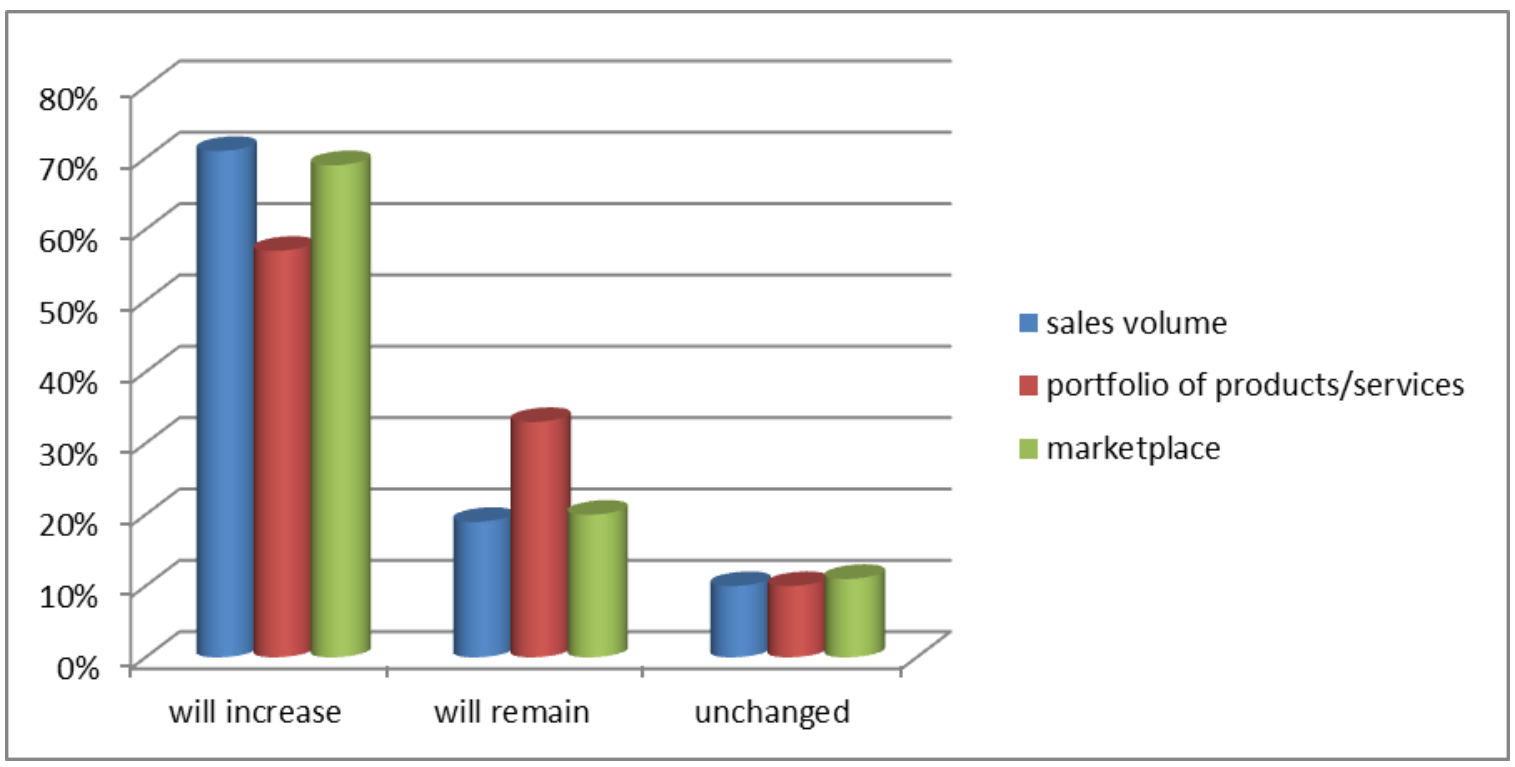

Figure 3. Assessment of the respondents' own business development opportunities

Source: own study

Such plans of the respondents are, of course, associated with the need for their companies to gain an advantage over their main competitors. They were to be helped by the advantages described in Figure 4. They put good atmosphere at work, employee loyalty, interpersonal relations and level of business experience in the first place. They considered the level of financial resources or creativity to be less important, but this cannot come as a surprise after previous data analysis.

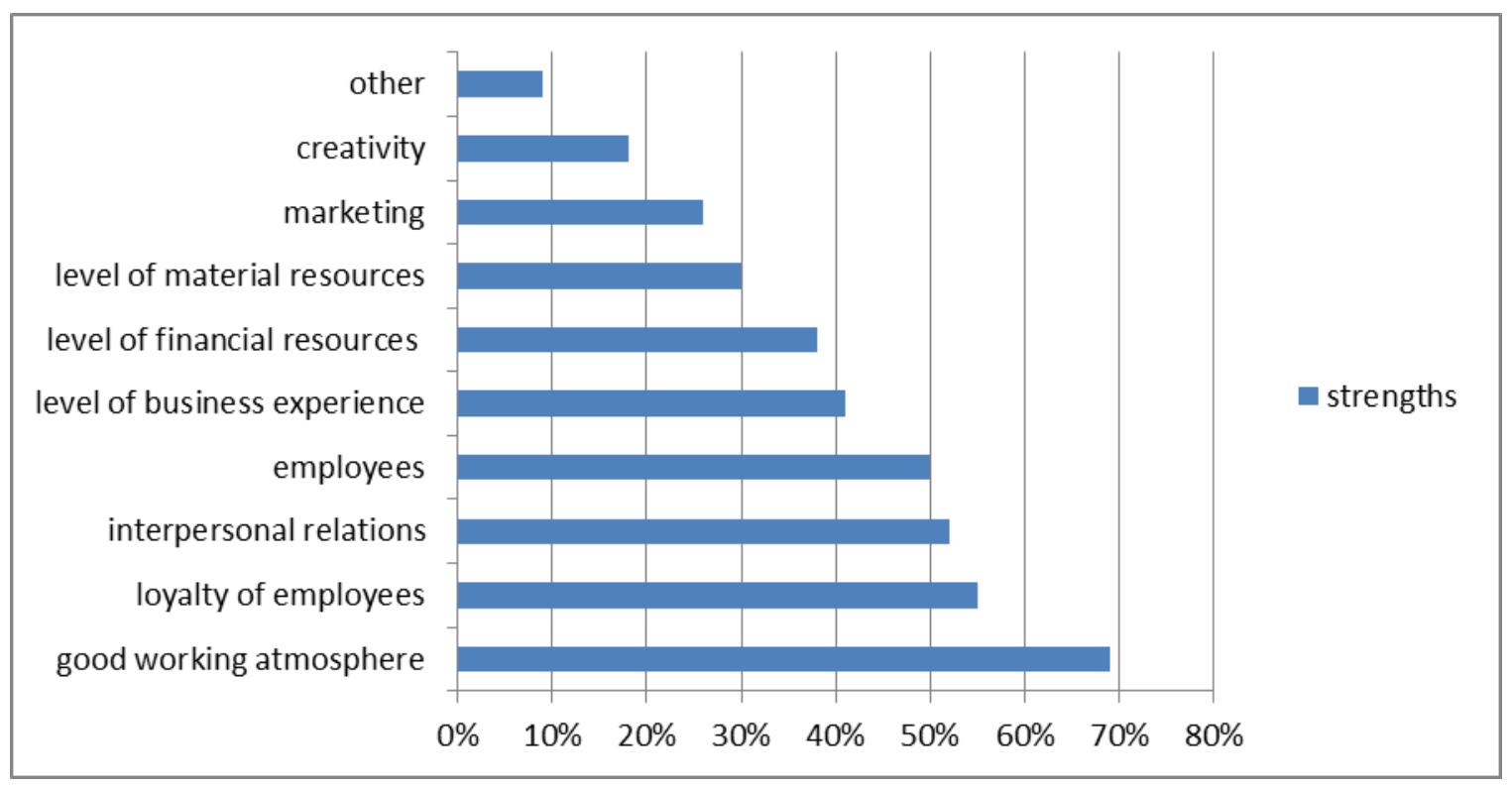

Figure 4. Strengths in building competitive position of the surveyed companies

Source: own study 
In this part of the analysis of research results, the author decided to focus on the internal conditions of enterprise development, i.e. determinants related to the characteristics of enterprises, their management systems and actions taken by entrepreneurs. The obtained data and conclusions are certainly consistent with modern business models of enterprises, which in the era of knowledge-based economy, attach great importance to human capital, business cooperation and intense competitive competition. Taking into account the functioning of the surveyed enterprises in terms of the number of employees, served clients, the value of equity capital, the size of revenues, the author noted that the vast majority of respondents stated an improvement in the situation in their enterprises. Most people referred to the increase in the value of net revenues - for $72 \%$ of entities and to the improvement in the competitive position of entrepreneurs - 66\% of entities (Figure 5).

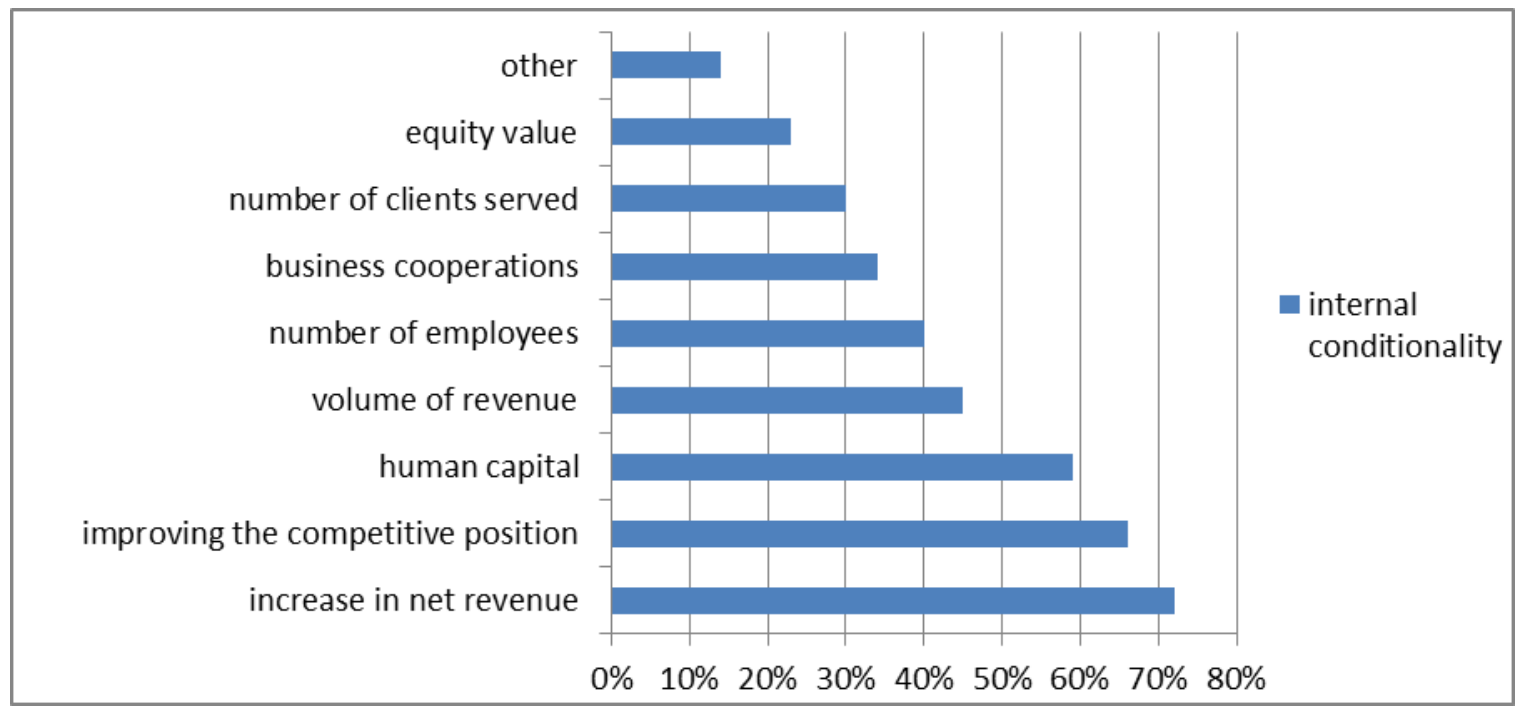

Figure 5. Conditions for internal development of enterprises

Source: own study

Another important factor, which the respondents have commented on, is business cooperation with other entities, including suppliers. Their selection is determined by specific criteria and the importance attributed to them by the respondents. The quality of offered goods/services, prices, availability, offer and market position were considered the most important. Small importance was assigned to the location of partners (distance), type of business or direct knowledge of it (Figure 6). 


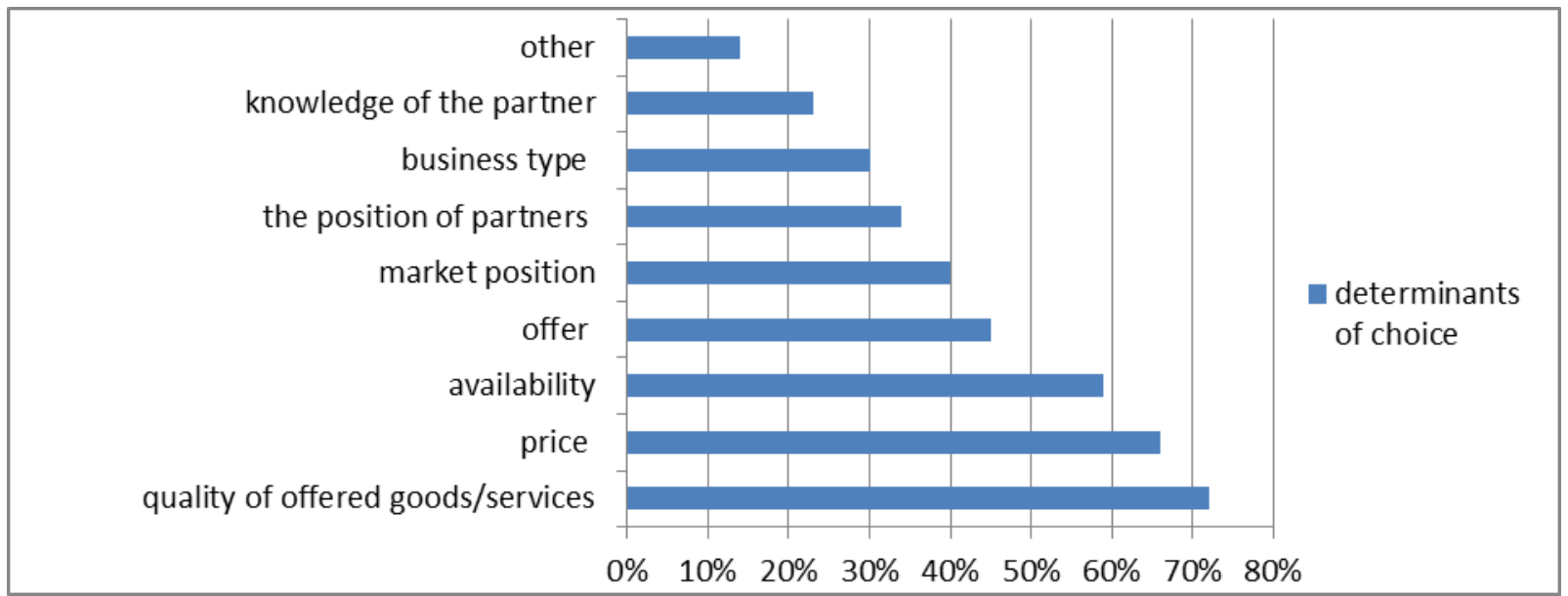

Figure 6. Determinants for selecting business partners

Source: own study

The internal conditions of conducting business activity may also include the impact of actions taken by entrepreneurs in relation to their competitors during the fight for the client. The analysis of the collected data shows that there is quite a lot of competition on the market, which was evaluated at the level of 4.6 points on a 5stage scale and which is noticed by $89 \%$ of the surveyed persons. Respondents, in order to win and keep their customers, most often bet on nice service, high quality of goods, products and services and working hours adjusted to customers' needs. They try to influence purchasing decisions by applying discounts. Depending on the industry and size of their business they also provide free transport and additional gratuities in the form of socalled gifts. They also make it possible to make purchases in installments and offer loyalty cards.

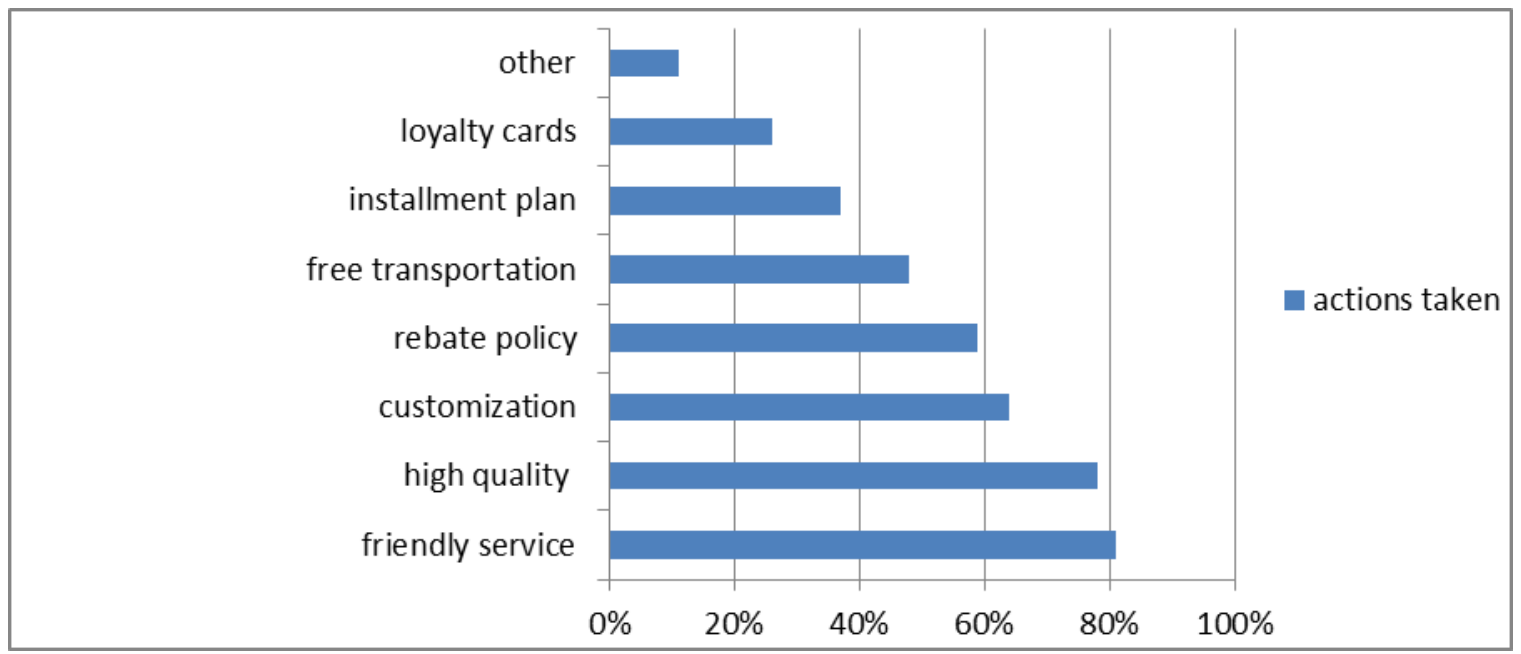

Figure 7. Activities used in the ,fight for the customer”

Source: own study

In order to assess the investment prospects of the surveyed companies (development plans), the author of the article included in the questionnaire the questions which concerned the planned investments in the next 3 years: 
investments in fixed assets, innovative activities, research and development and the increase in employment of specialists. In the light of the results obtained, more than half of the entrepreneurs planned investment outlays on fixed assets, $23 \%$ on the increase in employment, and about $10 \%$ on innovative and research and development activity (Figure 8). These are surprising results in the context of the identified gap in the improvement of their management systems - only $18 \%$ of the respondents have implemented activities in this area in the last two years of activity. To make matters worse, only $10 \%$ of this group stated that they managed to achieve a positive effect of the actions taken. Such results allow us to conclude that there is a very large, so far unused development potential, which, if used well, can definitely increase the effectiveness of the SME sector in Poland (Figure 9).

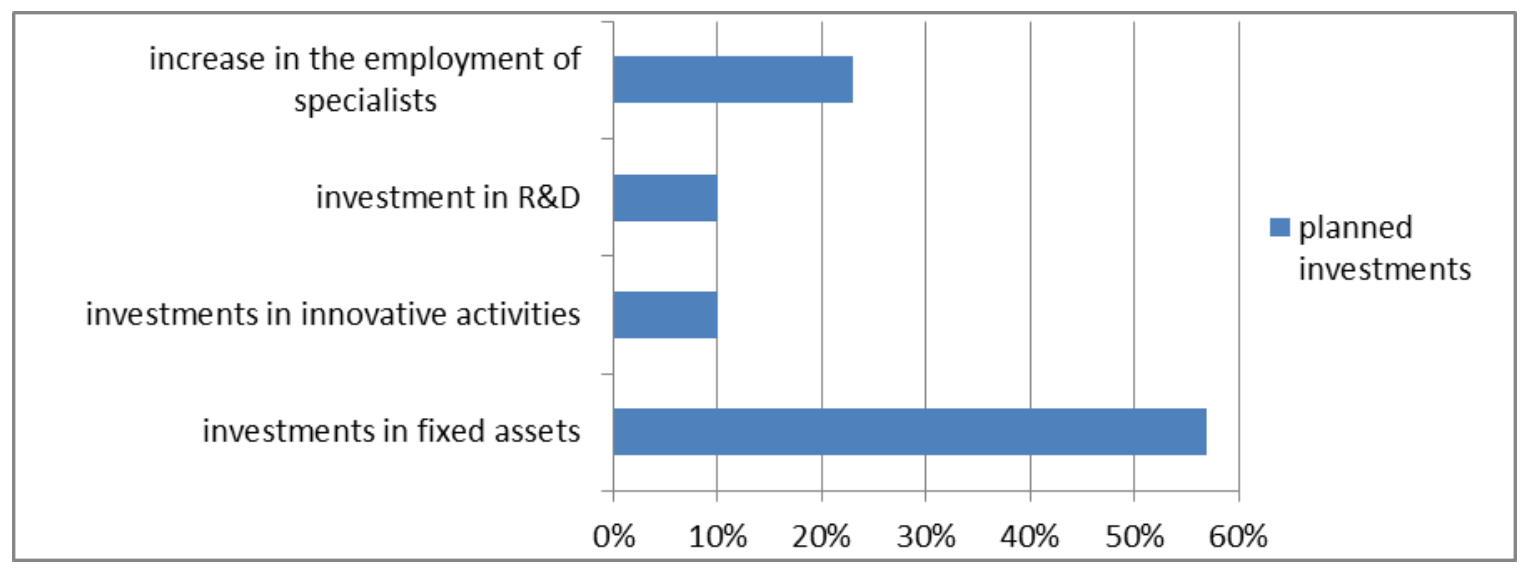

Figure 8. Investment perspectives of the surveyed companies Source: own study

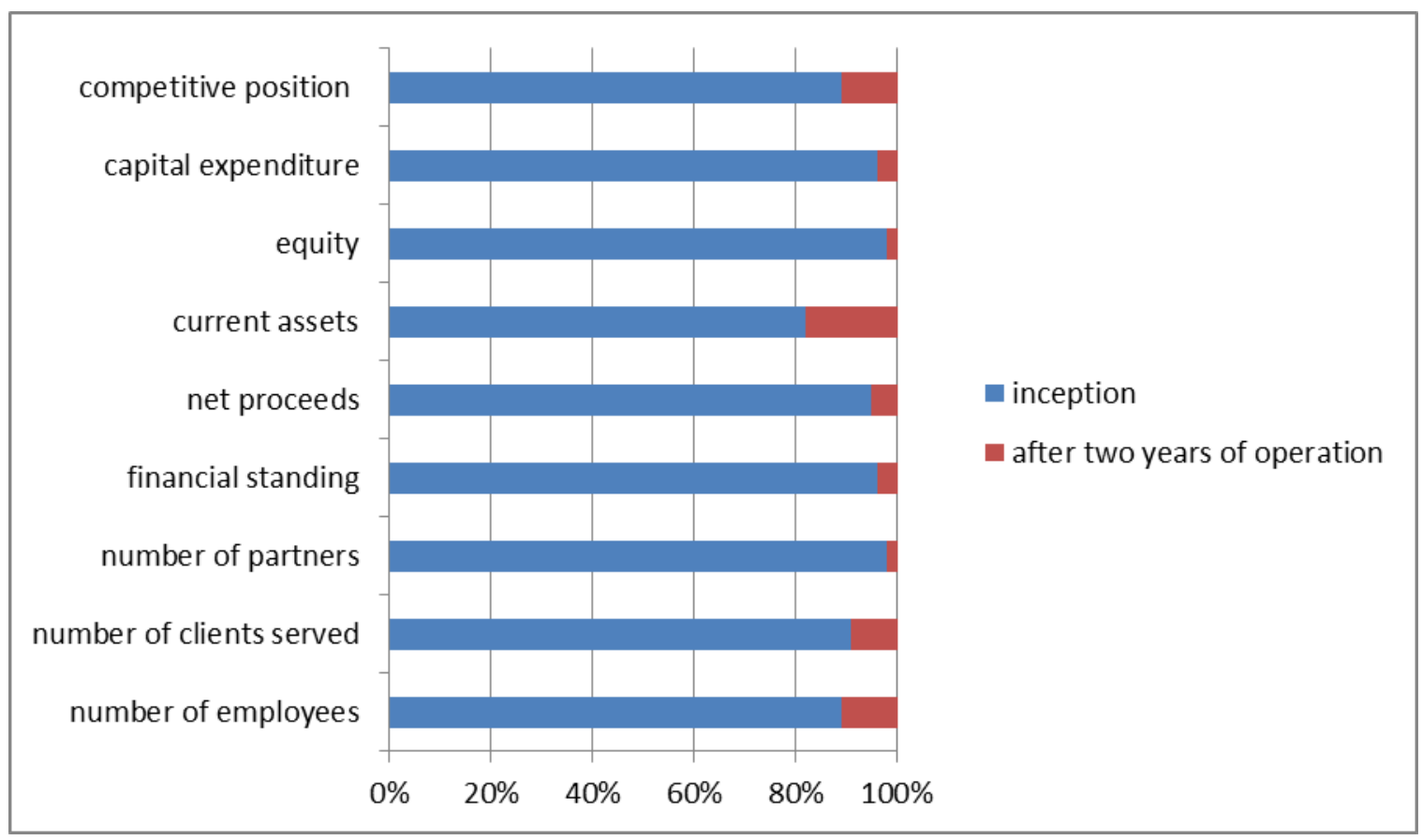

Figure 9. Identified investment gaps in management systems Source: own study 
Obviously, the biggest challenge may be to obtain the necessary financial resources. In many cases the barrier is also the inability to organize cooperation with business partners, due to organizational and technological immaturity. However, on the basis of the collected material, the author claims that there is quite a common awareness among Polish entrepreneurs of the importance of human capital and its optimal management. They know that they have to get as much of their employees as possible to succeed. They try to build commitment of the team, while they strive for $28.4 \%$ of teamwork, cooperation and care about building an integrated team. They know that in the 21 st century this is a key determinant of the market success of their companies. Unfortunately, the lack of an appropriate organizational culture and failure to implement programs for the company's most important employees makes it impossible for them to retain key employees. They also cannot find new, equally talented employees in their place. What should be the foundation of the new order in the company? It turns out that the owners of the surveyed entities are perfectly aware of it, see Figure 10.

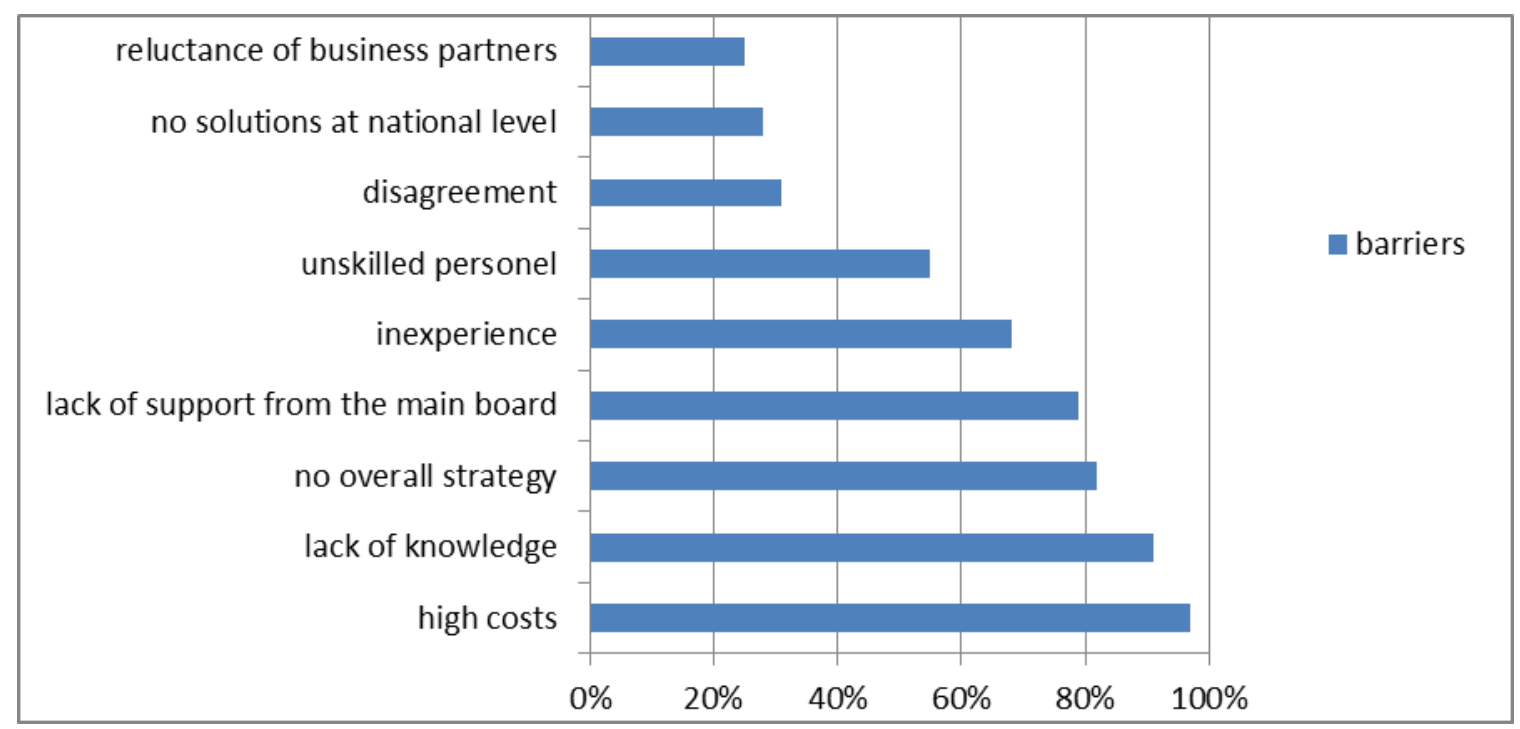

Figure 10. Barriers to optimal human capital management Source: own study

As we can see it is above all cooperation that bypasses existing structures and divisions. In many companies, a very big problem is the separate functioning of people responsible for business, and separate for technology. This effectively makes it difficult to take advantage of the opportunities brought about by economic changes. Of course, it is also necessary to have clear leadership, which does not run away from difficult decisions and treats subordinates in a partner way. And most importantly, you need to define your capabilities and establish strategies to avoid falling behind. After all, the key success factor is not technology per se, but people who can use it effectively. But why don't we do it? Don't we want to use people's potential as a weapon to fight new challenges? Don't we forget about the necessity of system solutions, starting with changes in organizational structures and cultures. These questions are undoubtedly the starting point for identifying innovative tools of human capital management in new economic conditions.

\section{Discusstion}

Entrepreneurship, as the author of the article has already written, is a very broad, multifaceted and interdisciplinary issue. There are many definitions of entrepreneurship in the scientific literature. We can see a certain evolution of views that emphasize various aspects of entrepreneurship - for example, in the dimension of 


\section{ENTREPRENEURSHIP AND SUSTAINABILITY ISSUES}

ISSN 2345-0282 (online) http://jssidoi.org/jesi/ 2021 Volume 9 Number 1 (September) http://doi.org/10.9770/jesi.2021.9.1(20)

behavior, entrepreneurship is identified with the ability to see new opportunities, the search for opportunities, the effectiveness of achieving goals, maximizing profits, achieving success. The author also assumed that the development of an enterprise is an aggregate of its growth, development, competitive position, development intentions and the current balance of the enterprise, both in the material and social sense. Currently, there is no fixed list of factors of development of the SME sector. Its variability results from the fact that in various studies of enterprises, new factors determining significantly their development and growth processes are usually determined. An example of such a factor is the so-called entrepreneurial orientation, which is an aggregation of the pursuit of implementing innovative solutions that refresh and improve the market offer, the ability to take the risk of implementing untested solutions and being more proactive than rivals in the use of market opportunities. Other variables of this type are market orientation, which is related to market monitoring and introduction of new business models. It may also be the introduction of human resource management models that are based on participation, commitment and activity.

Currently, there is no fixed list of factors of development of the SME sector. Its variability results from the fact that in various studies of enterprises, new factors determining significantly their development and growth processes are usually determined. An example of such a factor is the so-called entrepreneurial orientation, which is an aggregation of the pursuit of implementing innovative solutions that refresh and improve the market offer, the ability to take the risk of implementing untested solutions and being more proactive than rivals in the use of market opportunities. Other variables of this type are market orientation, which is related to market monitoring and introduction of new business models. It may also be the introduction of human resource management models that are based on participation, commitment and activity.

The development process is a long-term phenomenon that operates in the economy and includes quantitative and qualitative changes. The quantitative changes include: production growth, investments, employment, employment structure, income, the size of the operating capital, and other economic quantities that exist in the quantitative sphere of the economy. In practice, the quantitative changes that occur most often result in qualitative changes (Komańda \& Klosa, 2020). According to the author of the article, the most important of them is the change in the organization of society. In such a situation we can consider as the basic factors of economic development: human capital, entrepreneurship, land and raw materials, technical progress and investments. This phenomenon is particularly visible on the economic market in the first twenty years of the XXI century. Of course, this process is dominated by intensifying globalization processes, causing permanent market turbulence. This phenomenon leads to the emergence of new, previously unprecedented changes. Thus, we can distinguish many factors determining the development of economic activities, which may differ significantly or be practically identical.

Therefore, it is difficult for us to create a single, comprehensive and, most importantly, universal definition of the company's development. After all, this concept is difficult for us to identify and interpret, let alone define. According to the author of the article, the main reason for these problems is the fact that in every economic organization that carries out a specific activity, the development may take place in completely different areas of the economy or will be associated with different goals. Of course, you can try to define economic development following M. Krezymon (2018) - this is a development taking place during the process of change, which may concern a part of the company or its whole and relate to all or one area of operation. The company's development can be considered as the elimination of developmental discrepancies, i.e. the so-called development gap or as a process of improving the place occupied by the company in its environment (Augustyńczyk, 2020). According to other researchers, development is a process based on values, cooperation and science. This leads to improvement and strengthening of the company strategy. This is done by simultaneously strengthening processes, strategies, cultures and people forming one company. This leads to an increase in the efficiency of the business unit. As elements of development we can distinguish here changes in the structure of systems, improvement of the existing system or its elements and introduction of innovative changes to the existing system (Glinka \& Piaseczny, 2015). 


\section{ENTREPRENEURSHIP AND SUSTAINABILITY ISSUES}

ISSN 2345-0282 (online) http://jssidoi.org/jesi/

2021 Volume 9 Number 1 (September)

http://doi.org/10.9770/jesi.2021.9.1(20)

Development is also more and more often defined as quality, which is another factor in the company's development. The customer currently has a wide range of the same or similar products or services that are offered by companies. Therefore, their quality should meet certain standards or be higher than customers' expectations. Quality is a good thanks to which an entrepreneur has a possibility to build permanent, based on mutual trust, relations with a client and is one of the most important factors of a company's development. The development can also refer to the desire to survive on the market, maintaining the chosen scale of production and form of activity. Then its determinant becomes a person or persons managing an economic unit. Their strategic, marketing and analytical activities lead to maintaining market stability (Mitek \& Micuła, 2013).

To sum up, a survey with 200 business owners, which was launched in Poland over the last 5 years, allowed the author to collect data which, in his opinion, will allow him to try (this is a pilot study for the time being) to create the construction of the previously described measures of entrepreneurship development. These measures were used in the analysis as dependent variables, the effects of certain groups of factors. This means that the sequence of research tasks carried out in this article allowed, in the author's opinion, to develop and implement the main objectives of the prepared material set out at the outset. On the other hand, the obtained conclusions may find theoretical and practical application - serve for better cognition, understanding and improvement of the management of the determinants of entrepreneurship development in the face of new challenges.

On the other hand, we can certainly say that determinants of entrepreneurship development will permanently remain an element of management - as they have become tangible assets, organizational structures, strategies, processes, systems, financial and information resources. If we take into account the permanent changes, which are taking place in the economy, the determinants connected with the development of entrepreneurship will also change - and this is the most important value for the economy in the 21st century. All the more, so in view of the fifth industrial revolution. In science, on the other hand, we can hope that the need to develop these and new conceptual frameworks, together with methods for studying the determinants of entrepreneurship development, will not disappear.

\section{Conclusions}

In this article the author has attempted to identify the factors / determinants of the development of entrepreneurship, which are most important from the point of view of entrepreneurs themselves. In his research he paid special attention to external and internal conditions.

Certainly, the financial aspect had the greatest influence on making the decision about „own business” among the surveyed respondents, and only then the pursuit of self-fulfilment and the desire to be independent. However, the main sources of financing for the development of companies from the research group were considered to be own resources. This confirms the common conviction about piling up barriers on the way to acquiring foreign capital, i.e. loans or financial resources from loan funds. For the respondents, the development of the companies turned out to be conditioned also by acquiring and, what is important, retaining clients, which resulted in indicating many implemented actions that are to be a guarantee of success in this respect.

Moreover, from the collected empirical material it appeared that entrepreneurs saw the importance for the development and success of many of the analyzed internal factors - they attributed great importance to innovative management methods and human capital. They also did not forget about increased competitive competition, in the face of market saturation with entities of similar size, which have similar or even identical products or services in their offer. Certainly, an important factor connected with the development of business activity is the owner's person - his personality traits of entrepreneurs, for example professional competence or consistency in action. 


\section{ENTREPRENEURSHIP AND SUSTAINABILITY ISSUES}

ISSN 2345-0282 (online) http://jssidoi.org/jesi/

2021 Volume 9 Number 1 (September)

http://doi.org/10.9770/jesi.2021.9.1(20)

Additionally, the author, thanks to the analysis of source data, managed to obtain information from which we can obtain very interesting conclusions, which were not described above. Almost 19\% of adults are involved in entrepreneurship in Poland - just over 15\% in Europe. The percentage of companies that have not been operating on the market for more than 5 years (they are the main research group) is now almost $9 \%$. Interestingly, if we translate this into figures, we can state that 2.2 million Poles run the so-called young companies - for comparison, the percentage in Europe is $8.1 \%$. This is a sure sign that nowadays more and more adults in Poland think that their own company is a good way to make a career. On the other hand, people who have set up their own companies and succeeded in their business should be recognized. Poles are also more and more often able to see business opportunities in their environment and, what is important, they believe that they have enough skills and knowledge to run a company.

To sum up, according to the author of the article, the conditions for the creation and development of enterprises in Poland against the background of economies focused on innovation are not the best. However, there is a basis for optimism for the future, as most of the nine areas that form the primary basis for the identification of indicators / determinants of entrepreneurship development in Poland, in this survey was assessed positively by respondents. Unfortunately, all of the results of the survey are for the period up to 2020 and, in the author's opinion, reflect a very good economic situation and good situation on the labour market. This makes it easier to see the chances of setting up a company in their environment and at the same time less afraid of failure. We can only hope that in the new economic landscape, the landscape after the COVID-19 pandemic, the mood but also the actual state of the existing economy will also encourage optimism. Certainly, in connection with the dynamic changes taking place on the economic markets and the growing demand for information on the determinants of development and building competitive advantage of the SME sector, the author of the article plans to implement the described study on a larger group of entrepreneurs and their enterprises so that the results obtained are adequate for the entire population.

\section{References}

Augustyńczyk, J. (2020). Przedsiębiorczość w wybranych teoriach ekonomicznych (Entrepreneurship in selected economic theories). W. E. Gruszewska (red.), Współczesne problemu ekonomiczne w badaniach młodych naukowców. Teoria i praktyka (s. 28-42). Białystok (Poland): Wydawnictwo Uniwersytetu Białostockiego. https:///oi.org/10.15290/wpewbmn4.2020.02

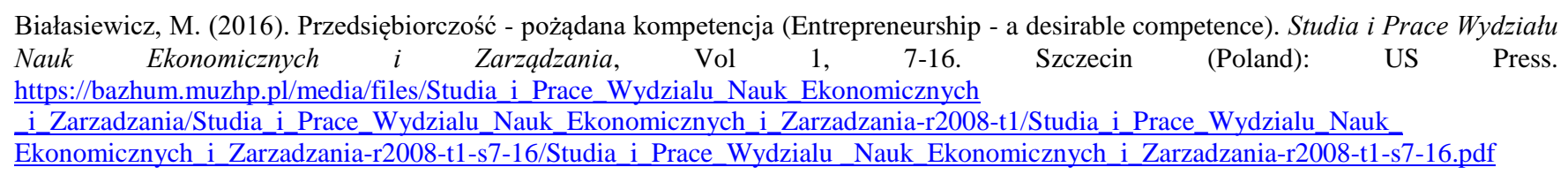

Glinka, B., \& Pasieczny, J. (2015). Tworzenie przedsiębiorstwa. Szanse, realizacja, rozwój (Enterprise creation. Opportunities, implementation, development). Warszawa (Poland): Wydawnictwo Uniwersytetu Warszawskiego.

Kaliszczak, L., \& Sieradzka K. (2020). Kształtowanie postaw przedsiębiorczych studentów wobec współczesnych wyzwań rozwojowych. (Shaping entrepreneurial attitudes of students towards contemporary development challenges). Entrepreneurship - Education, 16(2), 99114. https://p-e.up.krakow.pl/article/view/7760

Komańda, M., \& Klosa, E. (2020). Enterprises Approaches to Information Sharing in Supply Chain Risk Management. Zeszyty Naukowe Wyższej Szkoły Humanitas. Zarządzanie, 21(2), 137-151. http://yadda.icm.edu.pl/yadda/element/bwmeta1.element.ekon-element$\underline{000171597507}$ 


\section{ENTREPRENEURSHIP AND SUSTAINABILITY ISSUES}

ISSN 2345-0282 (online) http://jssidoi.org/jesi/ 2021 Volume 9 Number 1 (September)

http://doi.org/10.9770/jesi.2021.9.1(20)

Krezymon, M. (2018). Determinanty rozwoju przedsiębiorstw sektora MSP (Progress Development of Eneterprises in SME Sector). Wspótczesne Problemy Ekonomiczne, 18(2), 23-31. http://yadda.icm.edu.pl/yadda/element/bwmeta1.element.ekon-element-000171584426

Łochnicka, D. (2016). Przedsiębiorczość pracownicza i jej wpływ na efektywność organizacji (Employee entrepreneurship and its impact on organisational effectiveness). Łódź (Poland): Wydawnictwo Uniwersytetu Łódzkiego.

Mitek, A., \& Micuła, I. (2012). Wspótczesne determinanty rozwoju przedsiębiorstw prywatnych (Contemporary determinants of private enterprise development). Wspótczesne wyzwania gospodarowania i zarządzania. Warszawa (Poland): PWE.

O’Rourke, P. J. (2019). Adam Smith. Bogactwo narodów (The wealth of nations). Warszawa (Poland): MUZA Press.

Say, J. B. (2018). Revolutionary, entreprenuer, economist. New York (USA): Routlegde Press.

Shane, S., Venkataraman, S. (2013). A General Theory of Entrepreneurship. The Individual - Opportunity Nexus. Northampton (England): Edward Elgar Pub.

Targalski, J. (2014). Przedsiębiorczość i zarządzanie małym i średnim przedsiębiorstwem (Entrepreneurship and management of small and medium-sized enterprises). Warszawa (Poland): Difin.

Thornton, M. (2016). Richard Cantillon and the Discovery of Opportunity Cost. History of Political Economy, 39(1), 97-120. https://citeseerx.ist.psu.edu/viewdoc/download?doi=10.1.1.192.6748\&rep=rep1\&type=pdf

Mchal IGIELSKI Ph.D., Gdynia, Maritime University. Research interests: human resources management, entrepreneurship, competitiveness

ORCID ID: orcid.org/0000-0003-4680-3733

Make your research more visible, join the Twitter account of ENTREPRENEURSHIP AND SUSTAINABILITY ISSUES: @Entrepr69728810

Copyright (C) 2021 by author(s) and VsI Entrepreneurship and Sustainability Center This work is licensed under the Creative Commons Attribution International License (CC BY). http://creativecommons.org/licenses/by/4.0/

(c) † Open Access

